\title{
Economic benefits of livestock management in Ghana
}

\author{
Faizal Adams ${ }^{*}$ D, Kwasi Ohene-Yankyera, Robert Aidoo and Camillus Abawiera Wongnaa
}

\author{
* Correspondence: fazztop@gmail. \\ com \\ Department of Agricultural \\ Economics, Agribusiness and \\ Extension, College of Agriculture \\ and Natural Resources, Kwame \\ Nkrumah University of Science and \\ Technology, Kumasi, Ghana
}

\begin{abstract}
The traditional system of producing small ruminants (sheep and goats) contributes significantly to the socioeconomic wellbeing of farm households in northern Ghana. Besides serving as an important source of income, sheep and goats also offer important non-pecuniary benefits such as the provision of manure, savings, insurance, farm portfolio diversification, and strong social relations. However, technical evaluation of traditional small ruminant systems places much emphasis on financial gains to farmers and abstracts on the non-conventional utilities derived from the livestock system. The main purpose of this study, therefore, is to estimate the overall economic benefits associated with traditional small ruminant systems by accounting for both market and non-market values in two agro-ecological zones (Guinea and Sudan savannah) of northern Ghana. Using a multistage sampling technique, we collected cross-sectional data from 249 small ruminant farmers for empirical analysis. The results show that at least $60 \%$ of the net benefits from sheep and goat production in northern Ghana are in non-marketable (non-cash) forms. The study demonstrates that the traditional free-range system of managing sheep and goats is economically viable when the non-market value derived from the system is incorporated in the economic analysis. The findings have practical implications in improving the traditional small ruminant system for higher meat productivity and income generation in northern Ghana and elsewhere in sub-Saharan Africa (SSA).

Keywords: Economic value, Non-market products, Small ruminants, Food security, Productivity, Rural livelihood
\end{abstract}

\section{Introduction}

Numerous livestock development policies and programs for sub-Saharan African economies tend to contribute less to livestock production and productivity for poverty reduction and food security among rural households (Hatab et al. 2019). Production of livestock in the arid regions of sub-Saharan Africa reflects the traditional livestock systems (Verpoorten 2009) where the animals scavenge for their own feed, water, and shelter with little or no veterinary services (Covarrubias et al. 2012). However, the livestock animals are raised to meet multiple objectives of subsistence farmers (Onyango et al. 2015). The animals are managed not only for monetary benefits, but also for socioeconomic benefits, including hide, manure, source of medium-term savings,

(c) The Author(s). 2021 Open Access This article is licensed under a Creative Commons Attribution 4.0 International License, which permits use, sharing, adaptation, distribution and reproduction in any medium or format, as long as you give appropriate credit to the original author(s) and the source, provide a link to the Creative Commons licence, and indicate if changes were made. The images or other third party material in this article are included in the article's Creative Commons licence, unless indicated otherwise in a credit line to the material. If material is not included in the article's Creative Commons licence and your intended use is not permitted by statutory regulation or exceeds the permitted use, you will need to obtain permission directly from the copyright holder. To view a copy of this licence, visit http://creativecommons.org/licenses/by/4.0/. 
insurance against crop failure, means of diversifying investment, as well as to perform social and cultural functions (gifts, christening ceremonies) (Weyori et al. 2018).

The multiple functions of livestock in rural farm households make the production system complex (Salmon et al. 2018). However, the recent focus of livestock development programs has overlooked these complexities (Cook et al. 2015), thereby creating a divergent opinion between livestock technical staff and subsistence farmers (Moll 2003). The outcome is ineffective livestock policies, which are partly responsible for the low livestock production across sub-Saharan African countries, particularly Ghana (Salmon et al. 2018). It is therefore recommended that the inclusion of these socioeconomic and cultural functions would improve the success of livestock development efforts, considerations that are now being practiced in other countries (Ejlertsen et al. 2013; Traore et al. 2017).

A major reason for the limited consideration of the non-market co-benefits in livestock policies is attributed to valuation difficulties (Ouma et al. 2003). The primary analytical technique used by livestock technical staff and policy analysts to evaluate the traditional livestock system is the standard cost and benefit analysis (Al-Khalidi et al. 2013). However, such conventional analysis comes with a serious weakness in subsistence livestock production, where non-market features of the animals are as important as the market characteristics (Zezza et al. 2016).

In the livestock literature, while majority reported the importance of these additional non-pecuniary benefits (Weyori et al. 2018), only a few attempt to explain the underlying relationships between these co-benefits and biological production, and increased meat production, particularly for small ruminant animals (Alary et al. 2016). Even though small ruminants are even more important in providing economic stabilization to vulnerable households in rural economies (Al-Khalidi et al. 2013), no research has been conducted to evaluate the non-pecuniary function of these animals for policy recommendations across sub-Saharan Africa. This lack of literature is further exacerbated by the fact that most of the few existing studies focused on large ruminants, particularly cattle production (Siegmund-Schultze et al. 2011). Hence, it is difficult to make inferences for the small ruminant sector based on data from large ruminant production. Besides, most of the non-market evaluations of the traditional livestock production are limited to Eastern (Ayalew et al. 2003) and Southern Africa (Scoones 2003) with few exceptions in West Africa (Bosman et al. 1996). To the best of our knowledge, there is no published empirical study that estimates the non-market value of small ruminants that captures the effect of both sheep and goat production in Ghana and elsewhere in Africa. This study aims to fill the knowledge gap in small ruminant literature by estimating the non-pecuniary benefits of raising sheep and goats in the three (3) northern regions of Ghana. The three (3) regions investigated in this study are the most povertystricken, food insecure, and drought-prone zones of Ghana, where majority of the population subsists on small ruminants as a key livelihood coping strategy. Therefore, conducting this study in the regions provides technical knowledge and theoretical insight for a better understanding of the traditional small ruminant system for effective policy formulation.

The first aim of the study is to investigate the farmers' primary objectives for managing sheep and goats under the traditional production systems. Second, we estimate the overall economic value that accounts for both market and non-market benefits 
associated with managing rural small ruminant animals. The rest of the paper is organized as follows: the "Background" section outlines the background of the study, which details the socioeconomic importance of small ruminants in subsistence households; the "Methodology" section presents the methodology of the study; the "Results and discussions" section shows the results and discussions while the "Conclusion" section concentrates on conclusions and recommendations.

\section{Background}

Small ruminant livestock plays multiple roles (besides financial benefits from meat sales) in the wellbeing of poor and landless households in arid regions of sub-Saharan Africa (Bettencourt et al. 2015). First, for many farm households in rural economies, sheep and goat serve as a major form of savings and investment as well as financial security against deficits in household earnings. The animals also assume insurance role in rural livelihoods to overcome unforeseen necessities, including settling of medical bills and school fees (Verpoorten 2009). In rural Africa, financial markets are non-existent, or even if available, smallholder farmers face serious limitations in accessing services from them (Islam and Maitra 2012). In the absence of strong financial markets, livestock, including sheep and goats, is used as alternative forms of wealth accumulation (savings or financing) and risk-coping strategy (insurance) (Islam and Maitra 2012). The animals are, therefore, used as both short- and long-term savings against future needs.

Secondly, few agricultural enterprises, including crop production, can compete with small ruminants as a means of capital growth in poor and landless households. Initial capital to set up a small sheep and goat business is generally low, and the risk of animal loss is also relatively small (Onyango et al. 2015). Moreover, the smaller average size of sheep and goat makes the animals easier and quicker to sell than larger stock such as cattle, thereby serving as a potential source of liquid cash in times of financial need.

Sheep and goat also have advantages over other livestock in converting feeds such as straw and grasses, as well as other by-products such as kitchen scrap and other waste products into value-added, high-quality food products for household consumption (Bettencourt et al. 2015). The meat of small ruminants is a source of protein in many local cereal-based diets and can improve the nutrition of vulnerable children and pregnant women (Horasanli 2010). The size of small ruminants, which, on average, generates about 20 to 35kg carcass weight (Oppong-Anane 2011), allows rural households to conveniently process them easily for home consumption with little or no need for preservation (Lebbie 2004).

Small ruminants also play a significant role in improving the sustainability of smallholder farming systems (Devendra and Chantalakhana 2002). For instance, the manure from the animals helps to improve soil fertility, thereby saving farmers from the high cost of inorganic fertilizer (Karbo et al. 1997). Similarly, sheep and goats are also useful in controlling soil erosion and bush fires. Devendra and Chantalakhana (2002) argues that in many smallholder-farming communities, sheep and goats can browse on less productive and marginal lands covered with brushes and scrub trees. Such grazing practice helps to reduce potential fire hazards. Subsequently, the potential threat of rill and sheet erosion, when the land becomes exposed to rain and wind because of bushfire, is reduced (Lebbie 2004). 


\section{Methodology}

\section{Replacement cost theory}

The replacement cost ( $\mathrm{RC}$ ) method is one analytical framework commonly used in ecosystem valuations to estimate non-market values of environmental goods or services (Sundberg 2003; Ndebele 2009). According to Horasanli (2010), the RC approach falls under the class of the revealed preference (RP) theory, which stipulates that households' utilities are derived from the activities or actions they undertake, which eventually reveal their actual desires. The theory is based on observable data from actual behavior and choices of households rather than from probability choices as specified in random utility models (Baker and Ruting 2014).

As the name suggests, the $\mathrm{RC}$ method uses the opportunity costs of a nonmarket resource as a proxy to estimate the value of such resources (Sundberg 2003). The strength of the RC method is that the approach is cheaper, especially where data is readily available. In support, Baker and Ruting (2014) claimed that the value of resources that are classified as non-market cannot be estimated directly from market prices, which makes their valuations difficult. However, there is always a behavioral hint on the uses of the products that are suggestive of their values.

The weakness of the RC theory, however, is that it provides a rough indicator of economic value from available data. Another weakness is that, in rural economies where poverty and food insecurity issues are high, farm households' choices are not necessarily a true reflection of their desires and wants (Crawford and Rock 2014). Such households make production and consumption choices based on resources available to them and may not reveal their true preferences. Nonetheless, the technique has frequently been used because it provides approximations to measure the value of a product that is not traded on the market and has no market value (Horasanli 2010). The theory, therefore, is relevant in situations where the value of non-market products can be measured easily from the observed behavior of economic agents.

\section{Analytical framework}

This paper uses a two (2)-stage evaluation approach to estimate the overall economic benefits of the small ruminant system (Moll 2003). First, all resources and physical products from the production process are evaluated. Second, the nonpecuniary functions of small ruminants, including insurance and financing roles, are also estimated.

The resources used for small ruminant production are (i) external inputs and (ii) production factors contributed directly by the household, such as family labor, land, and capital. External inputs include medicines and drugs, feed supplements and fodder, hand tools, hired labor, and veterinary services. The animals convert these inputs through biological processes into recurrent (manure) and embodied (meat) products. The only recurrent product considered in this study is manure because indigenous goats and sheep in the study area do not produce milk. Therefore, the benefit realized from manure in a period $t, Y_{t}^{m}$, is defined as: 


$$
Y_{t}^{m}=\left(r_{j t}^{m} P_{j t}{ }^{m}\right)
$$

where $r_{j t}{ }^{m}$ is the quantity of ${ }^{1}$ manure, for $j$ small ruminant species, in period $t$, and $P_{j t}{ }^{m}$ is the price of manure, for $j$ small ruminant species, in period $t$. The amount of recurrent products produced from the production system depends largely on the animal species, sex, age, and season, and can be classified as non-market physical product.

The embodied products are classified into (i) non-market physical product and (ii) market physical product. The non-market physical product represents animals slaughtered for home consumption (during festivals and christening ceremonies) and animals used as gifts (in-kind) to strengthen social ties. Another important non-market physical product is the skin/hide derived from sheep and goat. In many instances, such products are excluded in the evaluation of subsistence livestock production systems. However, in rural areas such as northern Ghana, hide/skins are used for various purposes, including religious functions, sleeping carpet, making drums, leather for bags and shoes, and, most importantly, as sitting carpets for kings. The non-market physical product in period $t, Y_{t}^{k}$, is defined as:

$$
Y_{t}{ }^{k}=\left(r_{j t}{ }^{k} P_{j t}{ }^{k}\right)
$$

where $r_{j t}{ }^{k}$ is the quantity of non-market physical product $j$ in period $t$, with $j=$ number of sheep and goats used for home consumption, gifts, and quantity of hide/skin. $P_{j t}{ }^{k}$ is the price for non-market physical product $j$ in period $t$, with $j$ as defined above.

The market physical product (meat) in period $t, V_{t}^{e}$, is also estimated as:

$$
V_{t}^{e}=\left(O_{i}-I N_{i}+\text { net change in stock }\right) * P_{m i}-\sum X_{i} P_{i}
$$

where $O_{i}$ is outward transfers through only sales of $i$ animal (age, sex, and species), $I N_{i}$ is inward transfers including purchases and exchanges (gifts) of $i$ animal. The annual net change in stock refers to increases in stock through births. Hidden cost such as mortality and theft are also expressed in monetary value at the current market price per unit animal. $P_{m i}$ is the current price per unit animal; $X_{i}$ is the quantity of external input; $P_{i}$ is the price of external input $i$. The value of quantified benefits from meat could be negative due to a hidden cost of mortality and theft. Other losses such as morbidity are not accounted for in this research.

The sum of the recurrent products, non-market physical products, and market products (meat), over period $t$, results in gross margin (GM), for period $t$;

$$
\mathrm{GM}_{i}=Y_{t}^{m}+Y_{t}^{k}+V_{t}^{e}
$$

The financial role of livestock in rural communities has been highlighted in the scientific literature since the 1980s (Weyori et al. 2018). Recent studies continue to stress the relevance of non-pecuniary benefits associated with managing livestock in a rural setting, where formal financial markets are very weak or non-existent (Alary et al. 2016;

\footnotetext{
${ }^{1}$ The value of manure is determined from the key nutrients released to the soil (Fernandez-Rivera et al. 1993). The nutrients mainly, nitrogen and phosphorus, are then compared to similar nutrients in inorganic fertilizer to determine their monetary value. The proposed model by Fernandez-Rivera et al. (1993): Goat ( $F$ $\left.=\frac{26.5 g D M}{k g} W^{0.645}\right)$ and sheep $\left(F=32.0 g D M /{ }_{k g} W^{0.645}\right)$, was adopted to estimate the daily fecal dry matter $(F)$ from the animal's average body weight (W). The nitrogen content in $F$ is $1.5583 \%$ (Schelcht et al., 1997) and 0.55\% phosphorus (Somda et al. 1993) of the dry matter (DM).
} 
Weyori et al. 2018). Therefore, the livestock financing benefit is calculated solely based on the outflow of the stock (Bosman et al. 1996; Slingerland 2000). The benefit over a specified period, $t$, is determined by the sale price of outward transfers by a financing factor; $B_{t}^{f}$ :

$$
B_{t}^{f}=(\text { Total outflow } * P m) * b_{f}
$$

where the total outflow includes sheep and goats sold, consumed at home and used for gifts, $P m$ is the current price per unit animal, and $b_{f}$ is the financing factor in the study area calculated from the opportunity cost of alternative means of financing. Onyango et al. (2015) stated that interest rates from informal credit markets in rural Africa are highly variable and hence, taking the opportunity cost of credit from the formal credit market serves as a better proxy for financing factor. The insurance benefit, on the contrary, is estimated based on the premise that the entire flock is offered for sale to provide security in times of need (Weyori et al. 2018). Hence, the insurance benefit $B_{t}{ }^{i}$ is related to the monetary value of annual current stock of the animals.

$$
B_{t}{ }^{i}=(\text { average flock } * P m) * b_{i}
$$

where $b_{i}$ is the insurance factor estimated from the opportunity cost of informal insurance.

The aggregate annual net benefit in raising small ruminants is calculated as:

$$
\mathrm{TB}=\mathrm{GM}+{B_{t}}^{f}+B_{t}{ }^{i}
$$

where TB is annual total net benefit or overall economic value, and GM, $B_{t}^{f}$, and $B_{t}^{i}$ are as previously defined.

\section{Data and study area}

The study was carried out in the Guinea and Sudan Savannah agro-ecological zones of northern Ghana. The Guinea Savannah zone (GS) covers the entire Northern region and the lower part of the Upper West region of Ghana. On the other hand, the Sudan Savannah (SS) zone covers the northeastern part of the Upper East region of Ghana (Karbo and Agyare 1997). These two agro-ecologies exhibit characteristics of the arid and semi-arid zones, which are conducive for livestock production. The two zones together produce about $70 \%$ of Ghana's cattle stock and $75 \%$ of small ruminants in the country (Oppong-Anane 2011).

Three hundred (300) farm households (219 from GS and 81 from SS) were selected using a multistage sampling procedure. During the first stage, six (6) districts from the GS zone and three (3) districts from the SS zone that are very well-known for small ruminant production were purposively selected. For each of the selected districts, two (2) small ruminant-producing communities were chosen through simple balloting. At the final stage, the randomization function in Microsoft excel was applied to the list of farm households provided by the district Department of Agriculture to select the 300 respondents. Out of these respondents, 249 farm households who managed either one or more sheep and/or goats were subsequently considered for the study's analysis.

Field data collection was conducted through personal interviews using a standardized structured questionnaire. In addition to participant observation, a checklist was also 
employed to collect qualitative information through focus group discussions and key informant interviews.

Descriptive statistics, including arithmetic mean, standard deviation, simple proportion, and frequency distribution tables as well as graphs, were employed to summarize characteristics of respondents. The main reasons (objectives) to produce small ruminants were rated on a 4-point Likert type ranking scale (1=unimportant, 2=somewhat important, $3=$ important, $4=$ very important). Factor analysis was also conducted to group the various objectives for raising small ruminants. Independent sample $T$-test and gross margin estimations were performed during the valuation of the physical products obtained from sheep and goat production systems. The main benefits from small ruminant production system quantified in the study include meat for the market (sales), hide/skin, manure, non-cash savings against future expenses, insurance to meet unforeseen circumstances, and food risk management during drought/hunger periods. Others include satisfying religious rituals/faith, non-faith-based rituals, and gifting animals to strengthen social relations. The valuation process adopted in this paper has been presented in the analytical framework below.

\section{Results and discussions}

\section{Objectives of raising small ruminants}

A factor analysis was used to classify the primary benefits of managing small ruminants in northern Ghana. Ten (10) dimensions of benefits derived from small ruminant production are presented in Table 1. The Kaiser-Meyer-Olkin (KMO) measure of sampling adequacy was 0.633 , which justifies the application of factor analysis to the data. The outcome of the Bartlett's test of sphericity suggests that the relationship that exists among farmers' reasons for rearing small ruminants is strong. The test also shows a cumulative percentage variance of $51.77 \%$ of the components adopted in the study. The extraction coefficients indicate the amount of variance generated by each variable that is produced by the factors in the factor loading results. Hair Jr et al. (1998) recommended a factor loading of at least 0.335 as significant for a sample size between 200

Table 1 Extraction communalities of factors (main benefits)

\begin{tabular}{lll}
\hline Main purposes & Initial & Extraction coefficients \\
\hline Meat sales & 1.000 & 0.661 \\
Home consumption & 1.000 & 0.596 \\
Manure & 1.000 & 0.338 \\
Hide & 1.000 & 0.383 \\
Non-cash savings & 1.000 & 0.561 \\
Insurance (urgent need of cash) & 1.000 & 0.436 \\
Food risk management & 1.000 & 0.338 \\
Gifts & 1.000 & 0.487 \\
Religious rituals/faith-based rituals & 1.000 & 0.648 \\
Non-faith based cultural functions & 1.000 & 0.720 \\
Kaiser-Meyer-Olkin measure of sampling adequacy & & 0.633 \\
Bartlett's test of sphericity, approx. Chi-square (Dg = 45) & & $289.0^{\mathrm{a}}$ \\
\hline
\end{tabular}

Extraction method: principal component analysis; rotation method: Varimax Kaiser normalization ${ }^{a} 1 \%$ significant level 
and 300 respondents. All the factor loadings were significant and therefore considered in the subsequent analysis.

Three component elements were loaded after the iteration (Table 2). The first-factor component was labeled sociocultural, and the second, socioeconomic products. The third component factor, on the other hand, was labeled physical products. Factors under sociocultural products had the highest rotated component matrix, followed by socioeconomic factors, and finally physical products. The result implies that the use of sheep, goat, or a combination of the two to perform socioeconomic functions was next to sociocultural functions in terms of importance towards sustaining the rural farm family. Physical products were ranked third. The study supports prior findings that subsistence-farming households raise livestock in northern Ghana, mainly for sociocultural reasons (Saffu et al. 2009; Apori et al. 2010).

The component score matrix coefficient suggests that the use of small ruminants to perform religious/faith-based functions was the key motivating sociocultural factor for keeping the animals (correlation coefficient $=0.459$ ). This finding is consistent with that of Honya et al. (2007) and Saffu et al. (2009) who posited that livestock production is more of a tradition in northern Ghana. The authors argued that livestock management is part of early childhood development. Children are initially given fowls to rear and later rewarded with sheep or goat following a significant improvement in the management of the initial flock.

The data also reveal that the use of small ruminants as non-cash savings is the principal socioeconomic benefit derived from rearing sheep and goats (correlation coefficient $=0.471$ ). The result agrees with Apori et al. (2010) and Naadam and Mbilla (2010) who reported that financial security (i.e., non-cash savings) is one of the prime purposes for managing small ruminants under the traditional production system in Ghana. For instance, heightened food insecurity concerns among subsistence farming households in

Table 2 Rotated component matrix and component score coefficient matrix of factor analysis

\begin{tabular}{|c|c|c|c|c|c|c|}
\hline \multirow[t]{2}{*}{ Main purpose } & \multicolumn{3}{|c|}{ Rotated component matrix } & \multicolumn{3}{|c|}{ Component score coefficient matrix } \\
\hline & $\begin{array}{l}\text { Sociocultural } \\
\text { products }\end{array}$ & $\begin{array}{l}\text { Socioeconomic } \\
\text { products }\end{array}$ & $\begin{array}{l}\text { Physical } \\
\text { products }\end{array}$ & $\begin{array}{l}\text { Sociocultural } \\
\text { products }\end{array}$ & $\begin{array}{l}\text { Socioeconomic } \\
\text { products }\end{array}$ & $\begin{array}{l}\text { Physical } \\
\text { products }\end{array}$ \\
\hline $\begin{array}{l}\text { Non-faith-based } \\
\text { cultural rituals }\end{array}$ & 0.832 & & & 0.437 & & \\
\hline $\begin{array}{l}\text { Religious/faith-based } \\
\text { rituals }\end{array}$ & 0.790 & & & 0.459 & & \\
\hline $\begin{array}{l}\text { Non-cash savings } \\
\text { (against future } \\
\text { expenses) }\end{array}$ & & 0.745 & & & 0.471 & \\
\hline $\begin{array}{l}\text { Insurance (urgent } \\
\text { need of cash) }\end{array}$ & & 0.660 & & & 0.413 & \\
\hline $\begin{array}{l}\text { Food risk } \\
\text { management } \\
\text { (drought periods) }\end{array}$ & & 0.579 & & & 0.359 & \\
\hline Gifts & & 0.562 & & & & \\
\hline $\begin{array}{l}\text { Sales (regular income } \\
\text { source) }\end{array}$ & & & 0.723 & & & 0.545 \\
\hline Home consumption & & & 0.641 & & & 0.347 \\
\hline Hide & & & 0.606 & & & 0.380 \\
\hline Manure & & & 0.504 & & & -0.015 \\
\hline
\end{tabular}

Extraction method: principal component analysis; rotation method: Varimax Kaiser normalization 
northern Ghana are largely linked to crop failure as a result of long drought spells (Quaye 2008) and high incidence of poverty (Mackay and Aryeetey 2004). Such resource-poor farmers invest in small ruminants as non-cash savings (the so-called walking banks) to cope with food insecurity situations associated with such difficult periods.

The sale of sheep and goats to supplement household income is the most important physical advantage/factor for raising small ruminants (correlation coefficient $=0.545$ ). The finding is in synchrony with Apori et al. (2010) who observed that households manage small ruminants to provide regular income and meat in Ghana. Among urban dwellers, the demand for goat meat and mutton far exceeds supply (Adzitey 2013; Baah et al. 2012), suggesting a huge market with diverse opportunities to be exploited. According to Adzitey et al. (2010), goat meat and mutton are popular in Ghana and cherished in almost all Ghanaian communities with no consumption restrictions or taboo. Therefore, subsistence farmers can be assisted to harness such an opportunity to increase production for the market and help reduce poverty through the adoption of appropriate livestock policies.

\section{Cost of production}

From Table 3, the data depict an insignificant difference between the annual costs of external inputs for the two agro-ecological zones. Both zones have low annual input costs because the animals are managed under the traditional free-range system of

Table 3 Annual cost components (Ghథ) per household

\begin{tabular}{|c|c|c|}
\hline \multirow[t]{2}{*}{ Components } & \multicolumn{2}{|c|}{ Agro ecological zone } \\
\hline & Guinea savannah & Sudan savannah \\
\hline \multicolumn{3}{|c|}{ External cost (Ghana cedis) of managing small ruminants per household per year } \\
\hline Veterinary service & $22.10^{\mathrm{a}}$ & $23.08^{\mathrm{a}}$ \\
\hline Medicine/drugs & $12.73^{\mathrm{a}}$ & $9.25^{\mathrm{a}}$ \\
\hline Fencing/housing & $10.37^{\mathrm{a}}$ & $14.09^{\mathrm{a}}$ \\
\hline Dipping & $2.98^{\mathrm{a}}$ & $2.22^{\mathrm{a}}$ \\
\hline Feed supplements & $7.64^{\mathrm{a}}$ & $4.93^{\mathrm{a}}$ \\
\hline Total & $55.80^{\mathrm{a}}$ & $53.56^{\mathrm{a}}$ \\
\hline \multicolumn{3}{|c|}{ Hidden cost (Ghana cedis) of small ruminant per household per year } \\
\hline \multicolumn{3}{|l|}{ Sheep } \\
\hline Lambs 0-12 months & $53.00^{\mathrm{a}}$ & $33.27^{\mathrm{a}}$ \\
\hline Ewes & $69.16^{\mathrm{a}}$ & $102.73^{\mathrm{a}}$ \\
\hline Rams & $83.68^{\mathrm{a}}$ & $127.29^{\mathrm{a}}$ \\
\hline \multicolumn{3}{|l|}{ Goats } \\
\hline Kids $0-12$ months & $27.53^{\mathrm{a}}$ & $23.29^{a}$ \\
\hline Does & $51.90^{\mathrm{a}}$ & $75.33^{b}$ \\
\hline Bucks & $65.45^{\mathrm{a}}$ & $65.45^{\mathrm{a}}$ \\
\hline Total & $254.38^{\mathrm{a}}$ & $309.02^{\mathrm{a}}$ \\
\hline Overall production cos & & \\
\hline
\end{tabular}

Note: Within rows, means (least square mean values) of components with different superscripts are significantly different at $P<0.05$ on a $t$-test of means. Exchange rate: US\$1 was equivalent to Gh\$1.9 
production (Table 3). Such a system requires little or no purchase of external inputs, except the capital invested in the initial stock of the animals. Due to the free-range management system adopted, small ruminant production in both agro-ecologies is associated with higher costs arising out of lost animals due to theft and mortality. However, the null hypothesis of no difference in the values of lost animals in both agroecologies was sustained. The findings suggest high but similar production risks for both zones, probably because the animals are kept under similar conditions.

\section{Non-market physical products}

Based on the replacement cost theory, the monetary value of manure, financing, and insurance roles of small ruminants were estimated at prevailing expenditures on inorganic fertilizer, cost of capital, and insurance in the study area. All monetary estimates are reported in Ghana cedis at the official exchange rate of US\$1= Gh\$1.9 at the time of the survey.

First, the monetary values of active nitrogen $(\mathrm{N})$ and phosphorous $(\mathrm{P})$ in sheep and goat manure were estimated by using the equivalent price of $50 \mathrm{~kg}$ bag of NPK (15:15:15) fertilizer commonly applied to crop farms in the study area. In both agro-ecological zones, the price of 50kg NPK (15:15:15) was Gh\$45.00 (US\$23.6) which implies each active ingredient (16.7kg) costs Gh\$15.00 (US\$7.9). The average number of sheep and goats' holdings per household in GS was 20 and 16 for SS zones. Therefore, the total quantity of $\mathrm{N}$ and $\mathrm{P}$ contents estimated for the two zones is $0.035 \mathrm{~kg}$ in GS and $0.023 \mathrm{~kg}$ in SS. In monetary terms, the $0.035 \mathrm{~kg}$ in GS is equivalent to Ghष0.031 ((15*0.035)/16.7) while the $0.023 \mathrm{~kg}$ yields Gh 0.021 $\left(\left(15^{*} 0.023\right) / 16.7\right)$ in SS zone. As noted earlier, the sex, species type, and age of the animal were considered in the estimation process.

The number of sheep and goats used for home consumption, festivities, and other sociocultural activities (gifts) was also considered as non-marketed (physical) benefits. The monetary value of animals used to perform these functions was determined at the prevailing market price. At the time of the field survey, a kilogram of sheep or goat meat was sold for Gh\$7.7 in GS zone and Gh\$5.0 in the SS zone. In terms of weight $(\mathrm{kg})$, a typical farm household in GS used $19.23 \mathrm{~kg}$ and $5.5 \mathrm{~kg}$ of small ruminant meat for home consumption and gifts, respectively. Therefore, the monetary value of small ruminant meat consumed at home was Gh\$147.85 $(19.23 \mathrm{kg*}$ Gh\$7.7/ $\mathrm{kg})$ and that used for gifts amounted to Gh\$42.52 (5.5kg*7.7) in the zone.

In the SS zone, the average quantity of sheep and goat meat used for home consumption was $29.4 \mathrm{~kg}$. However, $13.4 \mathrm{~kg}$ of the meat was used for gifts to strengthen social relations. Hence, Gh\$146.8 (29.4kg* Gh\$5.0/kg) worth of sheep and goat meat was used for home consumption while Gh $\$ 67.23(13.4 \mathrm{kg*} G \mathrm{~h} \$ 5.0 / \mathrm{kg})$ was used to strengthen social relations in the SS zone.

The monetary value of hide (skin) was determined from the average sheep and goat holdings per household at slaughter age multiplied by the market price of skin obtained from local leather dealers. The average number of small ruminants' holdings at slaughter age per household in GS was eight (8). The equivalent leather price in the zone was Gh\$1.2. Consequently, the monetary value of the hide is estimated at Gh\$9.6. On the other hand, the equivalent skin price of leather in SS was Gh\$1.1 while the average 
animal holdings at slaughter age were six (6). This yielded Gh\$6.89 worth of small ruminant skin.

\section{Socioeconomic products (non-market)}

The value of two socioeconomic products of sheep and goats (financing and insurance role) was estimated. The average quantity of small ruminant holdings, measured in kilograms for GS, was $136.07 \mathrm{~kg}$ which is worth Gh\$1047.75 (136.07kg*Gh\$7.7/kg). Karlan et al. (2012) reported $8 \%$ as the insurance benefit factor for agricultural production in the study area. Hence, the insurance role of small ruminants was valued at Gh\$83.82 (Gh\$1047.75*0.08) in the GS zone. Similarly, insurance benefits worth of Gh\$69.2 (Gh\$865.0*0.08) were estimated for the SS zone based on $112.3 \mathrm{~kg}$ of small ruminants kept per household.

The financing role, on the other hand, was determined from total outflows (sold, gift, and home consumption) and the opportunity cost of capital. In the GS zone, the total outflow of $48.46 \mathrm{~kg}$ of small ruminant meat per household was valued at Gh\$373.2. With $20 \%$ as the opportunity cost of capital (interest on credit) at the time of the survey, the financing benefits of sheep and goats in GS zone were estimated at Gh\$74.64 (i.e., Gh\$373.2*0.2). In the Sudan savannah zone, the total financing benefit obtained from an outflow of $68.64 \mathrm{~kg}$ of small ruminants amounted to $\mathrm{Gh} \$ 68.64$ (Gh\$343.2*0.2).

\section{Physical products (gross margin)}

Illustrated in Table 4 are the gross margins of small ruminants in both agro-ecological zones. The significant difference in gross margins for the two zones is a result of a higher quantity of meat produced in the GS zone. This higher gross margin in GS was partly due to the greater number of sheep and/or goat sold and the increase in stock size through births (kids and lambs). Furthermore, there was a significant difference between the

Table 4 Gross margin component (Ghథ) across agro-ecologies

\begin{tabular}{|c|c|c|}
\hline \multirow[b]{2}{*}{ Components } & \multicolumn{2}{|c|}{ Agro-ecological zones } \\
\hline & GS $(n=120)$ & Sudan savannah $(n=129)$ \\
\hline Average flock size & $19.74^{\mathrm{a}}$ & $16.17^{\mathrm{b}}$ \\
\hline \multicolumn{3}{|l|}{ Physical products } \\
\hline \multicolumn{3}{|l|}{ Non-marketed products } \\
\hline Meat consumed at home & $147.85^{\mathrm{a}}$ & $146.80^{\mathrm{a}}$ \\
\hline Manure & $0.31^{\mathrm{a}}$ & $0.021^{\mathrm{a}}$ \\
\hline Hide & $9.36^{\mathrm{a}}$ & $6.89^{\mathrm{a}}$ \\
\hline In-kind & $42.52^{\mathrm{a}}$ & $67.23^{\mathrm{a}}$ \\
\hline Sub-totals $(A)$ & $198.13^{a}$ & $221.13^{a}$ \\
\hline \multicolumn{3}{|l|}{ Marketed products } \\
\hline Meat & $544.52^{\mathrm{a}}$ & $438.86^{\mathrm{b}}$ \\
\hline Less hidden cost (death/losses) & $254.38^{\mathrm{a}}$ & $309.02^{\mathrm{a}}$ \\
\hline Less external inputs & $55.80^{\mathrm{a}}$ & $53.56^{\mathrm{a}}$ \\
\hline Sub-totals (B) & $234.34^{\mathrm{a}}$ & $129.84^{b}$ \\
\hline Gross margin $(A+B)$ & $432.46^{\mathrm{a}}$ & $350.98^{\mathrm{b}}$ \\
\hline Gross margin per animal (GM/flock size) & $21.91^{\mathrm{a}}$ & $21.71^{b}$ \\
\hline
\end{tabular}

Note: Within rows, means (least square mean values) of components with different superscripts are significantly different at $P<0.05$ on a $t$-test of means. Exchange rate: US\$1 was equivalent to Gh\$1.9 at the time of the study 
average herd size per household in GS compared with the SS zone. Even though animal sales rate was low in the GS region, a high number of small ruminants given out in-kind to develop social relationships compensated for this. The results further reveal that there is no significant difference between gross margins per animal produced in the two agroecologies. The data also suggests no significant difference in the number of animals slaughtered to improve family nutrition in both agro-ecological zones.

Naturally, more than $58 \%$ of the gross margin per animal in the GS zone is lost due to the hidden cost of mortality compared with $88.1 \%$ in the SS zone. Ayalew et al. (2003) reported similar findings in Ethiopia. Such a high rate of losses can be attributed to the traditional free-range system practiced by households in the study area. Major factors responsible for the losses are disease and pest attack, theft, accidents, and predators' attack. These factors are comparable with the results of previous studies in different parts of Ghana (e.g., Karbo et al. 2007; Dei et al. 2010; Baah et al. 2012).

The relative contribution of non-market physical products to the gross margin in SS (63\%) and GS zone (46\%) reveals the comparative importance of small ruminants in household subsistence needs (Fig. 1). It appears that the individual animal products are either consumed or transferred (in-kind) with a small fraction offered in the market, especially in the SS agro-ecological zone. The monetary contribution of manure to the total physical products (gross margin) is insignificant. However, such evaluation provides a practical methodology to estimate the significance of manure for other larger livestock such as cattle. This is important because subsistence households frequently use cow dung (manure) as an alternative to inorganic fertilizer to promote the early growth of millet and sorghum in northern Ghana. Thus, strategies that improve the harvesting of such manure are desirable in order to increase crop production in the northern part of the country (Karbo et al. 1997).

\section{Aggregate (total net) benefit}

From Table 5, the financing benefit of sheep and goats in subsistence households is Gh\$75 in GS and Gh\$69 in SS per household per annum. The insurance role is

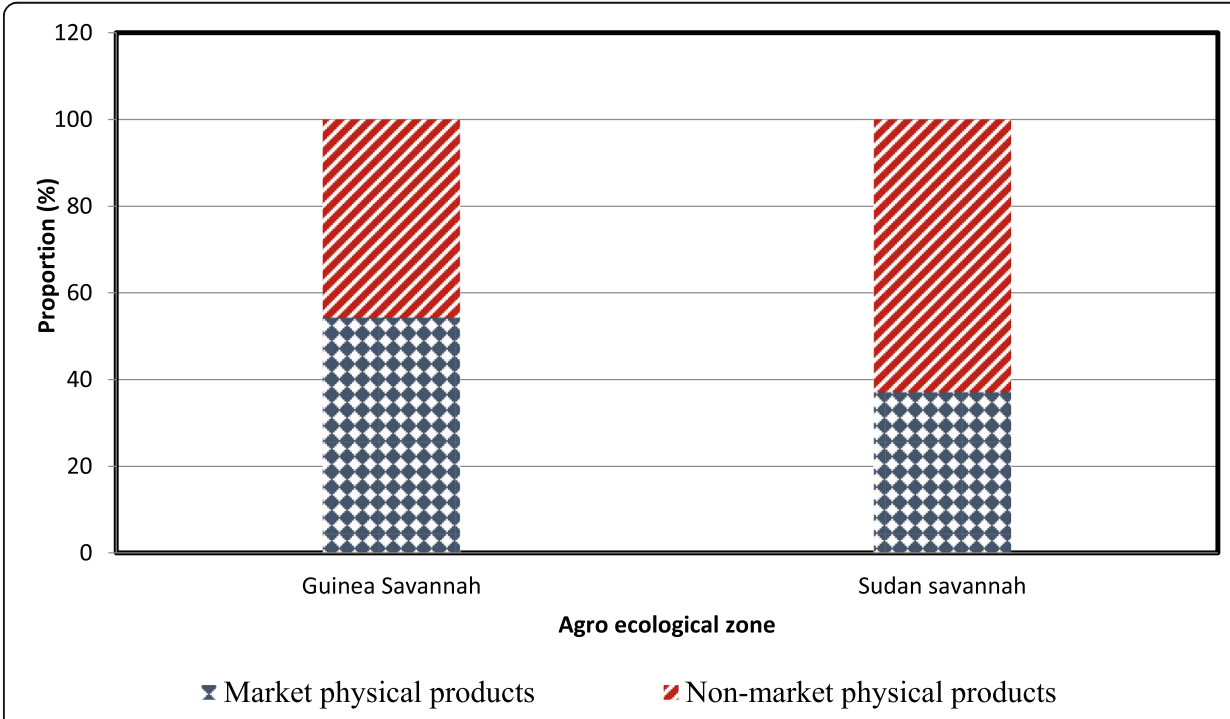

Fig. 1 Contribution of market and non-marketed physical products to gross margin 
Table 5 Socioeconomic benefits and aggregate net benefit from small ruminants for two agroecological zones per household

\begin{tabular}{|c|c|c|}
\hline \multirow[b]{2}{*}{ Components } & \multicolumn{2}{|l|}{ Agro-ecological zones } \\
\hline & Guinea savannah $(n=120)$ & Sudan savannah $(n=129)$ \\
\hline \multicolumn{3}{|l|}{ Socio-economic products } \\
\hline Insurance & $83.82^{\mathrm{a}}$ & $69.20^{b}$ \\
\hline Financing & $74.64^{\mathrm{a}}$ & $68.64^{a}$ \\
\hline Sub-total (C) & $158.46^{\mathrm{a}}$ & $137.84^{\mathrm{a}}$ \\
\hline Total net benefit $(A+B+C)$ & $590.92^{\mathrm{a}}$ & $488.82^{b}$ \\
\hline
\end{tabular}

Note: Within rows, means (least square means values) of components with different superscripts are significantly different at $P<0.05$ on a $t$-test of means. Exchange rate: US\$1 $=$ Gh\$1.9

estimated at Gh\$84 in GS and Gh\$69 in the SS zone. The total socioeconomic functions of the animals, therefore, are Gh\$158.46 and Gh\$137.84 in Guinea savannah and Sudan savannah zones, respectively. The benefits represent $27 \%$ in Guinea savannah and 29\% in Sudan savannah zones of the aggregate net benefit from sheep and goat production (Fig. 2). Even though the estimated values of the socioeconomic products are not different for the two agro-ecological zones, the annual aggregate net benefits of sheep and goats are significantly different for the two regions. The differences mainly came from the higher overall non-market contribution of small ruminant products in the GS agro-ecological zone.

As shown in Fig. 3, the overall non-market portion (that is, non-market physical and socioeconomic products) benefits represent $60 \%$ of the aggregate net benefit generated from small ruminant production in GS and $73 \%$ in the SS zone. The analysis implies that a large portion of the benefits realized from the traditional small ruminant system in northern Ghana is non-cash. The result compares well with Bosman et al. (1996), who reported that $80 \%$ of the total benefit achieved by managing goats in Southwestern Nigeria is non-marketable. Ouma et al. (2003) also made a similar observation in Kenya, where $77 \%$ of the total returns in managing cattle under the extensive livestock system were non-cash. Other studies (see, Ayalew et al. 2003; Scoones 2003) across sub-Saharan Africa also reported similar findings. The significance of raising sheep or goat in subsistence households in market terms alone is limited because the revenue generated from such market products is negligible. It contributes less than $40 \%$ in GS and $27 \%$ in SS of the aggregate net benefit.

The low market contribution in the SS region compared with GS agro-ecological zone highlights the importance of the non-pecuniary functions of sheep and goat towards food security and nutritional needs of poor and vulnerable households in rural communities. Official statistics indicate that nearly $90 \%$ of households in SS compared with less than $70 \%$ in GS agro-ecological zones are extremely poor. The data also suggest that about $34 \%$ of farm households from the SS region are food insecure against less than $10 \%$ in the GS zone (Biederlack and Rivers 2009). It was, therefore, normal that a larger proportion of small ruminant benefits in the SS zone is used to perform non-market functions, which represent an important livelihood strategy. For instance, gifts of animals provide a critical risk-coping strategy in marginalized and rural communities. During hardship, subsistence farmers tend to obtain some economic relief from family relations who previously received sheep or goat as gifts or part of share agreement (Bettencourt et al. 2015). In addition, the smaller size of sheep and goat 


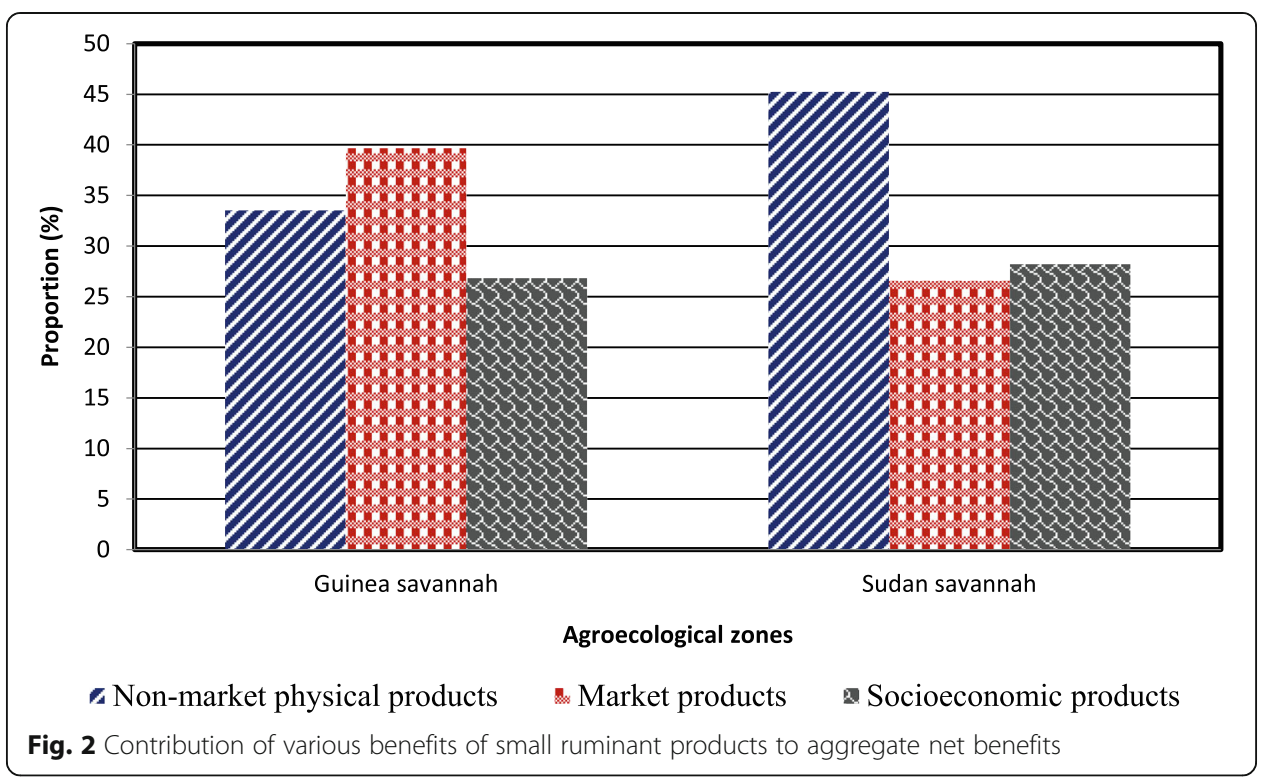

helps to improve poor households' nutrition since the animals are easily slaughtered for home consumption (Lebbie 2004). Moreover, such households manage food insecurity through the sale of animals when the need arises, especially during periods of drought and crop failure.

Essentially, the insurance and financing roles of small ruminants in rural households demand critical attention (Alary et al. 2016). This is so because the use of the animals to perform such socioeconomic functions is deeply rooted in subsistence livelihoods (Ayalew et al. 2003). Until less expensive, feasible, and attractive options of investment are provided to subsistence farmers, those functions of small ruminants will remain a permanent feature in the traditional production system (Ouma et al. 2003).

The consequences of holding the animals to satisfy these non-pecuniary motives come with serious negative implications on meat production and productivity for various reasons. First, subsistence farmers may hold "unproductive" animals in their herd for non-market (insurance or savings and financing) functions, thereby negatively affecting biological productivity (meat) and returns to household resources. Second,

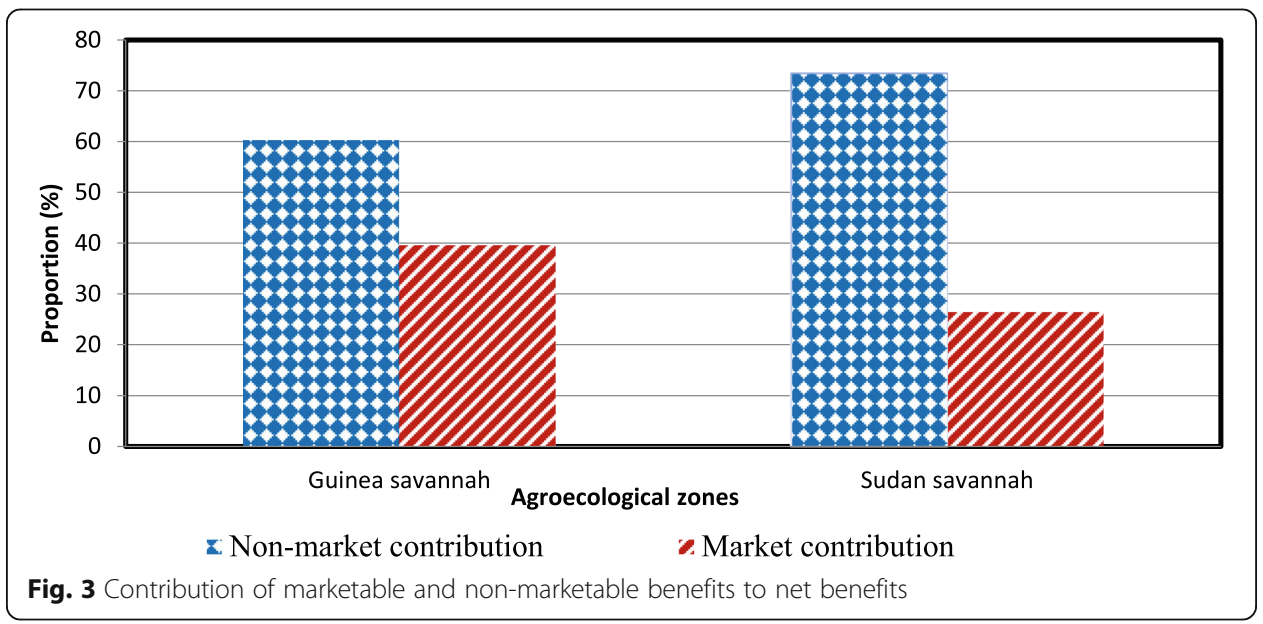


farmers may maintain sheep and goat in production beyond the animal's prime or economically optimum maturity stage for marketing to satisfy these non-market outputs. The resulting effect is the animals may become predisposed to high risks such as mortality, morbidity, and theft. The study affirms such high production risks associated with mortalities and losses in the traditional livestock system in the study area, where above $55 \%$ of sheep and goat market benefits were lost as a result of mortality and theft.

\section{Conclusion}

In summary, the study reveals that small ruminants under the traditional system are raised to perform multiple functions in rural farm households. The use of sheep and goats to perform important sociocultural functions such as faith- and non-faith-based cultural rituals was ranked first. This was closely followed by socio-economic functions (insurance and financing role) and finally, the use of physical products such as meat for sale, manure, hide, and home consumption in rural farm households. In support, the data show that a large portion (60\%) of the total benefit of sheep and goat production is to satisfy those non-pecuniary co-products, which are often ignored in economic studies of livestock systems. As a result, the production system is unaffected by marketing risk, but is confronted with high production, risks of mortality, morbidity, diseases, and theft. Pursuant to these non-market functions, subsistence farmers may hold sheep and goat in production beyond the animal's prime or economically optimum maturity. The resulting effect is that the animals become predisposed to many production risks. The status quo of the traditional small ruminant production systems is a permanent feature of the farming system because the non-market functions of the animals are deeply rooted in rural livelihoods. Therefore, there should be a convincing proposition that provides cost-effective and economic alternatives that will substitute the nonmarket role of sheep and goat. A pragmatic but long-term alternative is to actively incorporate smallholder farmers into formal financial and insurance markets. Appropriately integrating rural farmers into a viable crop, livestock, life, educational, and health insurance schemes, as well as financial markets, will not only entice farmers to become market-oriented producers, but will also help reduce the huge losses due to mortality and death associated with the traditional small ruminant system.

\section{Acknowledgements}

The authors highly appreciate funding under the Commonwealth Scholarship program in Canada, administered through the Federal Department of Foreign Affairs and International Trade (DFAIT) Canada, which sponsored the corresponding author's study exchange programme in Canada. We are also indebted to the financial support provided by the Ghana office of the International Food Policy Research Institute (IFPRI), for a research grant for the field survey of this manuscript.

\section{Authors' contributions}

FA wrote the proposal, collected the data and did the analysis, and wrote the paper. CAW also participated in the data collection and performed the analysis. KOY and RA edited and reviewed the manuscript. All the authors read and approved the manuscript for publication.

Funding

Data collection for this research was supported by grant from the International Food Policy Research Institute (IFPRI), Ghana, as part of PhD research work. However, no funding was extended to publish work from the research. 


\section{Declarations}

\section{Competing interest}

The authors declare that they have no competing interest.

Received: 9 May 2019 Revised: 2 February 2021

Accepted: 18 April 2021 Published online: 10 May 2021

\section{References}

Adzitey F (2013) Animal and meat production in Ghana-an overview. J World's Poultry Res 3(1):01-04

Adzitey F, Teye GA, Ayim AG, Addy S (2010) Microbial quality of chevon and mutton sold in Tamale Metropolis of Northern Ghana. J Appl Sci Environ Manage. 14(4):53-55. https://doi.org/10.4314/jasem.v14i4.63257

Alary V, Aboul-Naga AM, Abdelkrim M, El-Shafie MH (2016) Roles of small ruminants in rural livelihood improvement comparative analysis in Egypt. Rev Elev Med Vet Pays Trop. 68(2-3):79-85. https://doi.org/10.19182/remvt.20592

Al-Khalidi K, Alassaf AA, Al-Shudiefat MF, Tabini RJ (2013) Economic performance of small ruminant production in a protected area: a case study from Tell Ar-Rumman, A Mediterranean ecosystem in Jordan. Agric Food Econ 1(8). https://doi.org/1 $0.1186 / 2193-7532-1-8$

Apori SO, Osei DY, Oppong-Anane K (2010) Livestock marketing in the derived savannah zone of Ghana. In: Boa-Amposem K, Obese FY, Affedzie-Obresi S, Botchway AV (eds) Proceedings of the 30th Ghana Animal Science Association (GASA). Animal Science Association (GASA), Ghana

Ayalew WK, King JM, Bruns E, Rischkowsky B (2003) Economic evaluation of smallholder subsistence livestock production. Lessons from an Ethiopian goat development program. Ecol Econ 45(3):473-485. https://doi.org/10.1016/50921-8009(03 )00098-3

Baah J, Tuah AK, Addah W, Tait RM (2012) Small ruminant production characteristics in urban households in Ghana. Livestock Res Rural Dev 24 (86). available at: http://www.Irrd.org/lrrd24/5/baah24086.htm. Accessed 2 July 2013.

Baker R, Ruting B (2014) Environmental policy analysis: a quide to non-market valuation. Productivity Commission Staff Working Paper, Canberra Available at www.pc.gov.au. Accessed Jan 2019

Bettencourt EMV, Tilman M, Narciso V, Carvalho MLS, Henriques PDS (2015) The livestock roles in the wellbeing of rural communities of Timor-Leste. RESR, Piracicaba-SP 53(1):S063-S080. https://doi.org/10.1590/1234-56781806-94790053s01 005

Biederlack L, Rivers J (2009) Food security and vulnerability analysis (CSFA), Vam Food Security Analysis. World Food Program (WFP), Republic of Ghana. 2009. wfp.vaminfo@wfp.org. Accessed 14 Mar 2012.

Bosman HG, Moll HAJ, Udo HMJ (1996) Measuring and interpreting the benefits of goat keeping tropical farm systems. Agric Syst 53(4):349-372. https://doi.org/10.1016/S0308-521X(96)00047-9

Cook S, Silici L, Adolph B, Walker S (2015) Sustainable intensification revisited. International Institute for Environment and Development (IIED), Issue Paper. IIED, London https://pubs.iied.org/sites/default/files/pdfs/migrate/14651IIED.pdf

Covarrubias K, Nsiima L. Zezza A (2012). Livestock and rural livelihood in Tanzania. Joint paper of the World Bank, FAO, AUIBAR, ILRI, and Tanzania Ministry of Livestock and Fisheries. Available at: https://siteresources.worldbank.org/INTSURAGRI/ Resources/7420178-1294259038276/Livestock_Livelihoods_Tanzania.pdf. Accessed 16 Jan 2020.

Crawford I, Rock B (2014) Empirical revealed preference. Annu Rev Econ 6(5):3-524. https://doi.org/10.1146/annureveconomics-080213-041238

Dei HK, Konadu KO, Otchere EO, Djang-Fordjour T (2010) Housing of small ruminants in the Tolon-Kumbungu district of the Northern Region. In: Boa-Amposem K, Obese FY, Affedzie-Obresi S, Botchway AV (eds) Proceedings of the 30th Ghana Animal Science Association (GASA). Animal Science Association (GASA), Ghana

Devendra C, Chantalakhana C (2002) Animals, poor people and food security. Opportunities for improved livelihoods through efficient natural resource management. Outlook Agric 31(3):161-175. https://doi.org/10.5367/000000002101294010

Ejlertsen M, Poole J, Marshall K (2013) Traditional breeding objectives and practices of goat, sheep and cattle smallholders in the Gambia and implications in relation to the design of breeding interventions. Trop Anim Health Prod. 45(1):219-229. https://doi.org/10.1007/s11250-012-0194-1

Fernandez-Rivera S, TO W, Hiernaux P, Powel JM (1993) Faecal excretion by ruminants and manure availability for crop production in semi-arid West Africa. In: Powel JM, Fernandez-Rivera S, TO W, Renard C (eds) Proceedings of an International Conference on Livestock and Sustainable Nutrient Cycling in Mixed Farming Systems of Sub-Saharan Africa, Addis Ababa

Hair JF Jr, Anderson RE, Tatham RL (1998) Multivariate data analysis fifth, 5th edn. Prentice Hall, Upper Saddle River

Hatab AA, Cavinato MER, Lagerkvist CJ (2019) Urbanisation, livestock systems and food security in developing countries: A systematic review of literature, Food Security 11:279-299. https://doi.org/10.1007/s12571-019-00906-1

Honya G, Karbo N, Avornyo FK (2007) Micro-credit, household livestock production and food and nutrition security in Northern Ghana. The Savannah Farmer. Publication of the Association of Church Development Projects (ACDEP), Tamale, Ghana

Horasanli E (2010) Application of non-market economic valuation method to value the environmental benefits of geothermal energy in monetary terms: a case study in Yozgat province. Middle East Technical University, Turkey https://etd.lib.metu. edu.tr/upload/12612783/index.pdf

Islam A, Maitra P (2012) Health shocks and consumption smoothing in rural households: does microcredit have a role to play? J Dev Econ 97(2):232-243. https://doi.org/10.1016/j.jdeveco.2011.05.003

Karbo N, Agyare WA (1997) Crop-livestock systems in Northern Ghana. Improving crop-livestock systems in West and Central Africa. http://www.old.iita.org/cms/details/crop-livestock/arti16.pdf. Accessed Mar 2012.

Karbo N, Alhassan WS, Adongo SA, Bruce J (1997) Small holder lamb fattening based on crop residues and agro-industrial byproducts in Northern Ghana. Ghana J Agric 30:31-37

Karbo N, Otchere EO, Bruce J, Salia P, Honya G (2007) Small ruminant's ownership pattern, flock structure and aspects of their performance in a sedentary crop-livestock system of the Upper East region of Ghana. Ghanaian J Anim Sci 1(2):121-128 
Karlan D, Osei-Akoto R, Udry C (2012) Agricultural decisions after relaxing credit and risk constraints, NBER Working Paper No. 18463. http://www.nber.org/papers/w18463. Accessed May 2012

Lebbie SHB (2004) Goats under household conditions. Small Ruminant Res. 15(2):131-136. https://doi.org/10.1016/j.sma Ilrumres.2003.08.015

Mackay A, Aryeetey E (2004) Operationalizing pro-poor growth. A country case study on Ghana. Revised draft. A joint initiative of AFD, BMZ, DFID and the World Bank. http://siteresources.worldbank.org?INTPGI/Resources?34274-111505123 7044/oppgghana.pdf. Accessed Mar 2012

Moll HAJ (2003) Costs and benefits of livestock systems and the role of market and non-market relationships. Agric Econ 32(2):181-193. https://doi.org/10.1111/j.0169-5150.2005.00210.x

Naadam J, Mbilla S (2010) Perceptions about free ranging ruminants in Ghana: a case study of Bawku Municipality. In: BoaAmposem K, Obese FY, Affedzie-Obresi S, Botchway AV (eds) Proceedings of the 30th Ghana Animal Science Association (GASA). Animal Science Association (GASA), Ghana

Ndebele T (2009) Economic non-market valuation techniques: theory and application to ecosystems and ecosystem services. Massey University, New Zealand http://hdl.handle.net/10179/1287

Onyango D, Oyoko G, Too R, Masake R (2015). The contribution of livestock to the South Sudan economy. IGAD center for pastoral areas and livestock development (ICPLALD). Nairobi-Kenya. http://igad.int/attachments/714 TheContributionofLivestocktotheSudan584Economy.pdf(igad.int). Accessed 27 Jan 2020.

Oppong-Anane K (2011) Ghana livestock review report. Food and Agriculture Organisation (FAO), Rome, Italy

Ouma EA, Obare GA, Staal SJ (2003) Cattle as 587 assets. Assessment of non-market benefits from cattle in smallholder Kenyan crop-livestock systems. Proceedings of the 25th International Conference of Agricultural Economists (IAAE), Durban, South Africa 16-22 August 2003.

Quaye W (2008) Food security situation in Northern Ghana, coping strategies and related constraints. Afr J Agric Sci 3(5):334342

Saffu K, Apori SO, Elijah-Mensah A, Oppong-Anane K (2009) Livestock entrepreneurs from Northern Ghana. Their motivations and challenges. In: Sigue S (ed) Proceedings of the 10th Annual Conference. Reposition Africa Business and Development for the 21st Century (IAABD), Ghana, 2009

Salmon G, Teufel N, Baltenweck I, van Wijk M, Claessens L, Marshall K (2018) Trade-offs in livestock development at farm level: different actors with different objectives. Glob Food Security 17:103-112. https://doi.org/10.1016/.gfs.2018.04.002

Scoones I (2003) The economic value of livestock in the communal areas of Southern Zimbabwe. Agric Syst. 39(4):339-359. https://doi.org/10.1016/0308-521X(92)90074-X

Siegmund-Schultze M, Rischkowsky B, King JM (2011) Cattle as livestock. A concept for understanding and valuing the asset function of livestock. Outlook Agric 40(4):287-295. https://doi.org/10.5367/oa.2011.0065

Slingerland M (2000) Mixed farming, scope and constraints in West African savanna. Wageningen University and Research Centre, Wageningen.

Somda ZC, Powel JM, Fernandez-Rivera S, Reed J (1993) Feed factors affecting nutrient excretion by ruminants and the fate of nutrients when applied to soil. In: Powel JM, Fernandez-Rivera S, Williams TO, Renard C (eds) Livestock and sustainable nutrient cycling in mixed farming systems of sub-Saharan Africa., Addis Ababa, Ethiopia

Sundberg S (2003) Replacement costs as economic values of environmental change: a review and an application to Swedish sea trout habitats, Beijer International Institute of Ecological Economics. The Royal Swedish Academy of Sciences, SE10405, Stockholm

Traore SG, Fokou G, Ndour APN, Yougbare B, Kone P, Alonso S, Roesel K, Bakou SN, Dao D, Grace D, Bonfoh B (2017) Assessing knowledge, beliefs and practices related to the consumption of sheep and goat meat in Senegal. Glob Food Security 19:64-70. https://doi.org/10.1016/j.gfs.2018.10.001

Verpoorten M (2009) Household coping in war- and peacetime: cattle sales in Rwanda, 1991-2001. J Dev Econ 88(1):67-86. https://doi.org/10.1016/j.jdeveco.2008.01.003

Weyori AE, Liebenehm S, Hermann W (2018) Returns to livestock disease control-a panel data analysis in Togo. Eur Rev Agric Econ 47(2):1-30. https://doi.org/10.1093/erae/jbz031

Zezza A, Pica-Ciamarra U, Mugera HK, Mwisomba T, Okello P (2016) Measuring the role of livestock in the household economy. A guide for designing household survey questionnaires. LSMS, FAO and The World Bank document. Accessed http://www.fao.org/3/a-i6739e.pdf on January 2020.

\section{Publisher's Note}

Springer Nature remains neutral with regard to jurisdictional claims in published maps and institutional affiliations.

\section{Submit your manuscript to a SpringerOpen ${ }^{\circ}$ journal and benefit from:}

- Convenient online submission

- Rigorous peer review

- Open access: articles freely available online

- High visibility within the field

- Retaining the copyright to your article

Submit your next manuscript at $\boldsymbol{\Delta}$ springeropen.com 